\title{
The COVID-19 pandemic challenges physical activity with two emerging paradigms
}

\author{
A pandemia do COVID-19 confronta a atividade física com dois paradigmas \\ emergentes
}

\section{AUTHOR'S \\ Thiago Sousa Matias ${ }^{1}$ (D) \\ Fábio Hech Dominski ${ }^{2,3}$ (iD \\ 1 Federal University of Santa Catarina, Department of Physical Education, Research Center of \\ Physical Activity and Health, Research Center for Motivation and Human Movement Florianópolis, Santa Catarina, Brazil. \\ 2 Santa Catarina State University, Laboratory of Psychology of Sport and Exercise, Florianópolis, Santa Catarina, Brazil. \\ 3 Univille University, Department of Physical Education, Joinville, Santa Catarina, Brazil.}

\section{CORRESPONDING}

Thiago Sousa Matias

thiago.matias@ufsc.br

Campus Universitário Reitor João David Ferreira Lima, Centro de Desportos, Trindade,

Florianópolis, Santa Catarina, Brasil.

CEP: 88040-900.

DOI

$10.12820 /$ rbafs. $25 \mathrm{e} 0113$

\section{(cc) BY}

This work is licensed under a Creative Commons Attribution 4.0 International License.

\begin{abstract}
We are facing an unprecedented crisis due to the COVID-19, with social distancing measures. These measures have adverse impacts and exercise professionals need to gear efforts to promote active lifestyles. This assay has two purposes: 1) To discuss the role of web-based physical activity interventions during and after the COVID-19 pandemic, debating pros and cons, and offering preliminary guidance; 2) To discuss the role of physical activity on mental health, and proposing strategies to exercise interventions. We suggest a more positive outlook to web-based physical activity as internet can expand the scope of exercise as a self-care tool to health enhancement. The use of the internet as a professional tool to support exercise promotion can become a trend. Professional should weigh up the pros and cons when using such approach. After this pandemic we will cherish the psychological well-being benefits of exercise.
\end{abstract}

Keywords: Exercise; Internet-based intervention; Mental health; Communicable diseases.

RESUMO

Estamos enfrentando uma crise sem precedentes em virtude da pandemia de COVID-19 e isso inclui a necessidade de isolamento social. O isolamento social tem efeitos adversos para a saúde mental e manter um estilo de vida ativo é importante. Este ensaio tem como objetivo discutir a atividade física no formato remoto, assim como, a relação da atividade física e saúde mental. São evidenciados prós e contras da atividade física remota através da internet, além de recomendaçôes práticas. Observa-se que a promoção da atividade física remota, utilizando-se da internet, pode ampliar e favorecer o escopo da atividade física para o autocuidado e promoção da saúde. O uso da atividade física remota pode virar uma tendência, contudo, os profissionais devem equilibrar os prós e os contras quando da sua utilização. Evidencia-se que depois da pandemia os benefícios da atividade física sobre a saúde mental serão mais valorizados.

Palavras-chave: Atividade motora; Midias sociais; Saúde mental; Infecçôes por coronavirus.

\section{Introduction}

We are facing an unprecedented crisis due to the $\mathrm{Co}^{-}$ ronavirus Disease (COVID-19) pandemic, with social distancing measures aiming to slow the spread of the disease. However, these containment measures have adverse impacts on society, including psychological health, relationships and physical inactivity. In this sense, the Brazilian Journal of Physical Activity and Health launched a special namely, "Exercise/physical activity and COVID-19", with sub-themes, such as web-based physical activity interventions and the role of physical activity on mental health.

The present work offers a critical appraisal of the promotion of exercise/physical activity in remote mode, and the exercise/physical activity for mental health during social distancing. The COVID-19 pandemic is exacerbating physical inactivity and we pose a question directly related to public health: How can exercise professionals help people maintain or engage in physical activity even during social distancing?

Given that fitness centers and other training locations are temporarily closed, it is possible to see some opportunities for physical activity and health promotion and a way to delivery and facilitate accessibility in exercise programs. In this sense, online technologies (paradigm one) have seemed to be successful tools to increase 
physical activity levels, including telehealth, social media and other innovative platforms, such as Internetand Website-based physical activity interventions ${ }^{1}$.

Other major impacts caused by stay-at-home advisory are the negative psychological health consequenc$\mathrm{es}^{3}$. Recent evidence shows that social distancing related to pandemics is associated to stress disorder, confusion, feeling of loneliness, boredom and anger occurred during and after the mandatory quarantine ${ }^{2}$. Thus, the literature highlights the need to adopt policies that will reduce problems related to the depreciation of mental health ${ }^{2}$ and exercise appears to be key to prevent mental illness and promote well-being ${ }^{3}$ (paradigm two).

The negative consequences of social distancing are already happening; however, ways to ameliorate these issues need to be discussed. Therefore, this assay has two purposes: 1) To discuss the role of web-based physical activity interventions during and after the COVID-19 pandemic by reviewing literature, debating pros and cons, and offering preliminary guidance; 2) To discuss the role of physical activity on mental health, and proposing strategies to face-to-face and virtual exercise interventions.

\section{Web-based physical activity}

The role of web-based interventions for physical activity is not a novelty. There is an extensive body of evidence showing that the internet can be a way to promote physical activity in the general population.

Evidence shows that the effectiveness of web-based interventions in modifying behavior to enhance physical activity is related to increment of walk, increase in step count and promotion of moderate to vigorous physical activity ${ }^{4}$. These positive results can be explained on the basis of individuals' self-monitoring, goal setting ${ }^{5}$, and personalized feedback to physical activity, thereby stimulating behavior change. Research has demonstrated that web-based physical activity can have low implementation costs, be easy to manage and scalable ${ }^{1,5}$.

In times of the COVID-19 pandemic, we have seen the need for such technologies ${ }^{3}$. Many places that promote opportunities to be physically active, such as gyms and fitness centers, public parks, outpatient cardiac rehabilitation, school-based physical education and athletic programs, are temporally closed, which represents a decrement in infrastructure for people to be physically active. This, in turn, exacerbates physical inactivity and sedentary behavior. Thus, web-based physical activity interventions are fundamental to keep people active and safe in this critical period, but also in the post-pandemic period. Next, we considered the pros and the cons of using web-based physical activity as a tool to keep people physically active and to facilitate the engagement of people who are physically inactive before the COVID-19 pandemic.

\section{Pros}

Scientific publications have reported that recording exercise patterns through self-monitoring of physical activity facilitates people physical activity engagement ${ }^{4}$, given that people are free to choose when to access and download the exercise materials. This approach have shown benefits to increase physical activity, promote weight loss and improve health-related behavior, such as diet/nutritional intake, boosting self-management of risk factors ${ }^{1}$ and enhancing autonomy to physical activity, as people feel more in control of the behavior.

Settings such as rehabilitation programs have also been showing advantages of using web-based physical activity as patients can monitor themselves (increasing safety) and can monitor outcomes of the disease-related progress ${ }^{6}$. For older adults and individuals who have some underlying medical conditions that limit attendance to a rehabilitation program, web-based physical activity can be a reasonable way to maintain the rehabilitation program remotely.

The low implementation cost is a strong attribute of web-based physical activity interventions, which has the potential for reaching a large number of people and facilitates accessibility, as the activity is delivered in the comfort of their own homes. Furthermore, this type of activity could overcome the barriers to physical activity participation, namely lack of time, urban violence, need of transport, outdoor air pollution, weather conditions, and high costs ${ }^{7}$.

\section{Cons}

Despite the wide range of interventions, this type of activity is most likely to be delivered to young people and well-educated middle-aged people as well as people who are already motivated or physically active, due to their higher interest in online health services and resources ${ }^{8}$.

Another limitation of web-based physical activity is related to the absence of environmental and social dynamics, such as green exercise ${ }^{9}$, the contact with people and social support, and therefore the privation of synergistic benefits between feelings of connection 
to nature and the establishment of relatedness. The environmental restrictions also limit the types of physical activity such as contact team sports

\section{Is the glass half full or half empty?}

Even though the use of technology to promote physical activity is not a novelty, the internet has become a phenomenon during a pandemic state, and professionals have realized the full potential of these tools. Therefore, we suggest a more positive outlook: seeing the glass half full. It appears that the pandemic has demonstrated that the internet can expand the scope of educational and professional care and include people who possibly were not comfortable in a traditional physical activity setting.

For instance, the UK department for education provides access to online educational resources for children and young people, including physical education and physical activity to be performed at home. They can access a series of websites that create a more comfortable and fun environment where children can perform their exercises routines; as one of many examples, they encourage children to a 10-minute shake up, inspired by advice from Disney's and Pixar's characters ${ }^{10}$, promoting fun and a more supportive environment.

The American College of Sports Medicine ${ }^{11}$ provides several educational resources to certified exercise professionals in order to work in a virtual and online environment, also providing content during COVID-19 pandemic ${ }^{11}$. Those examples illustrate that webbased interventions are a reality and have been introduced into the set of core actions of organizations.

\section{Physical activity and mental health}

Responses to COVID-19 pandemic are associated with high levels of anxiety and distress; in fact, loneliness produces deleterious effects on mental health and low self-esteem creates vulnerability to depression ${ }^{3}$. The increments in psychological burden in the population are in line with evidence from similar pandemics ${ }^{2}$ and interventions to cope with critical stressors during and after this pandemic are paramount and physical activity as a self-care tool to health enhancement appears to be a key element.

Different theories have addressed a set of psychological needs which, when supported, provide individual's psychological growth and wellness, however, social distancing seems to hinder the foundation of these needs and physical exercise setting has been observed to be one of the most important behaviors to support essential psychological needs and to restore optimal activity through homeostasis ${ }^{3}$, which, in turn, prevents mental illness and promotes well-being ${ }^{12}$. But, what about exercising at home using web-based tools?

Two important points should be considered ${ }^{3}$ : a) exercising at home seems to lack of strict protocols, and physiological benefits on mental health cannot be guaranteed; and b) exercising at home may follow the individuals' own choice and volition, and psychological mediators may promote mental health.

Despite a possible contradiction, exercising at home has shown a more altruistic side of physical activity promotion (e.g. live stream videos). Professionals are encouraging people to exercise as an act of choice and volition, as well as to select the type, schedule, duration, frequency and intensity of exercises. When contrasting the social constraint imposed by social distancing, exercising at home may allow a deep feeling of satisfaction through the experience of autonomy; when autonomous forms of regulation guide behaviors, positive affective responses are expected ${ }^{13}$. We are suggesting that after the pandemic, the general population will understand and cherish the psychological well-being benefits of exercise.

\section{Exercising at home and psychological well-being: practical implications}

It is important to note that most of the worldwide population was physically inactive before the COVID-19 pandemic ${ }^{14}$. Thus, we cannot assume that people will be autonomous enough to pursue physical activity at home; this increases the responsibility of exercise professionals for creating strategies and organizing ways to engage people and keep them active during and after this pandemic.

It is noteworthy that if exercise continues to be delivered using the same justifications as before the pandemic (e.g. valuing physical-related gains such as aesthetic, valuing physical health, valuing weight loss and hypertrophy), physical gains will be obtained instead of significant emotional/behavioral gains.

For instance, these controlled justifications might not make much sense for people in social isolation, and the individuals' exercise behavior and related variables will probably not change into an autonomous conduct of life. It is crucial that physical activity intervention have a functional link to the assessed needs. Recently, Teixeira et al. ${ }^{13}$ consensus of techniques of health behavior change and 
Matias's ${ }^{15}$ book on motivation and behavioral change summarized techniques to enhance autonomous motivation through supporting basic psychological needs.

Overall guidance from the studies mentioned above suggests that physical activity settings (particularly important for exercising at home) should enhance the individual's experience of feeling empowered, provide choices as well as meaningful and value purposes for the activity, and should not interfere with external contingents, such as pressure and guilt.

We would like to propose some strategies that can be implemented to support psychological needs in face-to-face and virtual interventions. Figures 1a, 1b, and $1 \mathrm{c}$ show strategies to support psychological needs for autonomy, relatedness, and competence, respectively. The suggestions were based on the works conduct- ed by Teixeira et al. ${ }^{13}$ and Matias ${ }^{15}$. The strategies were adapted to represent a physical activity setting. We mainly consider strategies that can be delivered in-person manner and through on-line platforms.

\section{Final considerations}

Ultimately, the use of the internet as a professional tool to support exercise promotion can become a trend. There are several possibilities to get people moving through online technologies, either in online personal training classes or group training classes. It is highly important to weigh up the pros and cons when using such approach. Professionals and researchers should be aware of this and implement strategies to support physical activity maintenance, psychological needs, and consequently mental health promotion.

\begin{tabular}{|c|c|}
\hline \multicolumn{2}{|c|}{ Autonomy } \\
\hline Techniques & Operational strategies \\
\hline Provide different ways of achieving task objectives. & $\begin{array}{c}\text { Enable individuals to choose ways to solve tasks from a set of different } \\
\text { possibilities. }\end{array}$ \\
\hline Display openness to explore physical activity in different ways. & $\begin{array}{c}\text { Enable individual to learn about physical activity from other sources, such as } \\
\text { concepts and attitudes. Provide different types and variations of activities as } \\
\text { well as modalities to engage in physical activity. }\end{array}$ \\
\hline $\begin{array}{l}\text { Use informal language, avoid criticism and favor greater freedom of choice for } \\
\text { the individual. }\end{array}$ & $\begin{array}{l}\text { Avoid being another source of pressure for physical activity. Exercises are, in } \\
\text { many cases, performed as a way to achieve goals apart from the activity itself. }\end{array}$ \\
\hline $\begin{array}{l}\text { Set goals to perform physical activity that favors intrinsic motivation (e.g. } \\
\text { better lifestyle; having a pleasant moment during the day). }\end{array}$ & Set goals with more internal causal loci with individuals. \\
\hline $\begin{array}{l}\text { Provide individuals with opportunity to make choices about physical activity } \\
\text { actions (e.g. type, frequency, intensity), as well as about the possibility of not } \\
\text { performing this behavior. }\end{array}$ & $\begin{array}{l}\text { Encourage personal input and ownership over change in behavior and } \\
\text { responsibility through choice. }\end{array}$ \\
\hline $\begin{array}{l}\text { Promote situations that foster self-initiative and that the experience can be } \\
\text { pleasurable, challenging and offer opportunities to learn new skills. }\end{array}$ & $\begin{array}{l}\text { Provide input for individuals to autonomously try and search for other ways to } \\
\text { exercise (e.g. participate in an online dance class). }\end{array}$ \\
\hline $\begin{array}{l}\text { Organize activities that involve the individual's capacity of cognitive, motor } \\
\text { and psychological control. }\end{array}$ & $\begin{array}{l}\text { Allow a more comfortable adjustment of the body (e.g. cognitive, motor and } \\
\text { psychological) with the experience of movement. }\end{array}$ \\
\hline
\end{tabular}

Figure 1a - Strategies to support psychological need of autonomy

\begin{tabular}{|c|c|}
\hline \multicolumn{2}{|c|}{ Relatedness } \\
\hline Techniques & Operational strategies \\
\hline $\begin{array}{l}\text { Consider the individual's participation in the elaboration and planning of the } \\
\text { goals and assessment of his/her progress. }\end{array}$ & $\begin{array}{l}\text { Build an open and collaborative group environment to discuss goals to be } \\
\text { achieved, promoting attitudes of co-responsibility, trust and attachment. }\end{array}$ \\
\hline $\begin{array}{l}\text { Offer individuals alternatives to contact you in case of self-administered } \\
\text { classes/sessions. }\end{array}$ & $\begin{array}{l}\text { Favor autonomy, but strengthen the individual's capability to overcome the } \\
\text { barriers to self-administered physical training. }\end{array}$ \\
\hline $\begin{array}{l}\text { Encourage people to participate in events, programs and group challenges to } \\
\text { implement physical activity. }\end{array}$ & $\begin{array}{l}\text { Propose strategies that include people in situations during which social } \\
\text { support appears, providing information about programs, competitions (even } \\
\text { online) that can potentially provide positive affects. Suggest the participation } \\
\text { of family members in the activities. }\end{array}$ \\
\hline $\begin{array}{c}\text { Create situations that encourage group problem solving, associated or not } \\
\text { with physical activity. }\end{array}$ & $\begin{array}{l}\text { Propose the need for group task resolutions that approach the attitudinal and } \\
\text { conceptual dimensions of physical activity. }\end{array}$ \\
\hline Consider actively participating in activities. & $\begin{array}{l}\text { Produce a favorable environment for the health professional to be the source } \\
\text { of social support, being fully involved in the activity. }\end{array}$ \\
\hline Create possible culminating events. & $\begin{array}{l}\text { At the end of a set of classes, propose events to the group of students (e.g. } \\
\text { web-based challenges/competitions). }\end{array}$ \\
\hline Construct the group's social identity. & Strengthen the shared sense of belonging to a group. \\
\hline
\end{tabular}

Figure $1 \mathrm{~b}-$ Strategies to support psychological need of relatedness 


\begin{tabular}{|c|c|}
\hline \multicolumn{2}{|c|}{ Competence } \\
\hline Techniques & Operational strategies \\
\hline $\begin{array}{c}\text { Support learning and goal-setting processes in physical activity promotion } \\
\text { and associated behaviors. }\end{array}$ & Provide feedback of successful experiences associated with task completion. \\
\hline $\begin{array}{l}\text { Provide relevant personal and targeted feedback to inform more about the } \\
\text { process than about the outcome. }\end{array}$ & $\begin{array}{l}\text { Endorse the recognition of short-term achievements obtained through the } \\
\text { learning process. Value proximal goals instead of distal ones. }\end{array}$ \\
\hline $\begin{array}{l}\text { Support progress monitoring and improvement of skills and performance } \\
\text { by providing tools or creating structures that allow the individual's self- } \\
\text { assessment (e.g. encourage the use of a watch to monitor physical activity). }\end{array}$ & $\begin{array}{l}\text { Build up structures that reinforce progress toward pre-set goals, inform } \\
\text { success and maintain individual vigilance. }\end{array}$ \\
\hline Promote structures that allow challenges and moderate degrees of adventure. & $\begin{array}{l}\text { Favor situations in which the individuals are able to cognitively evaluate } \\
\text { the activity as challenging. These situations also should inspire the need to } \\
\text { overcome challenges and self-regulate performance to ensure improvements } \\
\text { (e.g. trying to exercise on unstable surfaces). }\end{array}$ \\
\hline $\begin{array}{l}\text { Promote activities that represent positive affective responses, such as pleasure } \\
\text { and satisfaction. }\end{array}$ & $\begin{array}{l}\text { Build up activities that use the social component of leisure sports (e.g. game } \\
\text { structure). }\end{array}$ \\
\hline
\end{tabular}

Figure 1c - Strategies to support psychological need of competence

Considering an approach in which people self-administrate exercise protocols, future studies should focus on the validation of these online tools and contents, as they have to be reliable and well-founded. We consider that using these tools does not exclude the primacy of face-to-face physical activity or outdoor physical activities; but it is an alternative in the event of environmental constraints. Also, web-based physical activity may help to decrease physical inactivity across the world given its democratic approach.

However, it is important to note that many people across the world are social vulnerable. They will not even consider engaging in physical activity since their thoughts are focused on meeting their essential basic needs first.

Physical activity and the health sector will not be the same after the COVID-19 pandemic. We should take this crisis as an opportunity to establish a broader context for physical activity as a self-care tool to promote psychological well-being.

\section{Conflict of interest}

The authors declare no conflict of interest.

\section{Authors' contributions}

Matias TS, conceived the presented idea and wrote the text. Dominski $\mathrm{FH}$, wrote the text and performed the review of the text.

\section{References}

1. Joseph RP, Durant NH, Benitez TJ, Pekmezi DW. Internetbased physical activity interventions. Am J Lifestyle Med. 2014;8(1):42-67.

2. Brooks SK, Webster RK, Smith LE, Woodland L, Wessely S, Greenberg N, et al. The psychological impact of quarantine and how to reduce it: rapid review of the evidence. The Lancet. 2020;395(102227):912-20.
3. Matias TS, Dominski FH, Marks D. Human needs in covid-19 isolation. J Health Psychol. 2020; 25(7):871-82.

4. Jahangiry L, Farhangi MA, Shab-Bidar S, Rezaei F, Pashaei T. Web-based physical activity interventions: a systematic review and meta-analysis of randomized controlled trials. Public Health. 2017;152:36-46.

5. Davies CA, Spence JC, Vandelanotte C, Caperchione CM, Mummery WK. Meta-analysis of internet-delivered interventions to increase physical activity levels. Int J Behav Nutr Phys Act. 2012;9(52):1-13.

6. Andersson G, Titov N. Advantages and limitations of Internet-based interventions for common mental disorders. World Psychiatry. 2014;13(1):4-11.

7. Centers for Disease Control and Prevention/CDC. Overcoming Barriers to Physical Activity. United States: 2020. [cited in 2020 May 5]. Available at: https://www.cdc. gov/physicalactivity/basics/adding-pa/barriers.html

8. Andreassen HK, Bujnowska-Fedak MM, Chronaki CE, Dumitru RC,Pudule I, Santana S, Wynn R. European citizens' use of E-health services: a study of seven countries. BMC Public Health. 2007;7(53):1-7.

9. Shanahan DF, Franco L, Lin BB, Gaston KJ, Fuller RA. The benefits of natural environments for physical activity. Sports Med. 2016;46(7):989-95.

10. GOV.UK. Guidance. Coronavirus (COVID 19): list of online education resources for home education. United Kingdom: 2020. [cited in 2020 May 7]. Available at: https://www. gov.uk/government/publications/coronavirus-covid-19online-education-resources/coronavirus-covid-19-list-ofonline-education-resources-for-home-education\#physicaleducation-pe-and-physical-activity.

11. American College of Sports Medicine/ACSM. Exercise Professional Resources. 2020. [cited in 2020 May 7]. Available at: https://www.acsm.org/learn-develop-professionally/ exercise-professional-resources.

12. Mandolesi L, Polverino A, Montuori S, Foti F, Ferraioli G, Sorrentino P, et al. Effects of physical exercise on cognitive functioning and wellbeing: biological and psychological benefits. Front Psychol. 2018;509(9):1-11.

13. Teixeira P, Marques M, Silva M, Brunet J, Duda J, Haerens L, et al. Classification of Techniques Used in Self-Determination Theory-Based Interventions in Health Contexts: An Expert Consensus Study. Motiv Sci. 2019; ahead of print. 
14. Guthold R, Stevens GA, Riley LM, Bull FC. Worldwide trends in insufficient physical activity from 2001 to 2016: a pooled analysis of 358 population-based surveys with $1 \cdot 9$ million

Received: 24/04/2020 participants. Lancet Glob Health. 2018;6(10):e1077-86.

15. Matias TS. Motivação, atividade física e mudança de comportamento: Teoria e Prática. 1 ed. Curitiba: Appris, 2019.

\section{Quote this article as:}

Matias TS, Dominski FH. The COVID-19 pandemic challenges physical activity with two emerging paradigms. Rev Bras Ativ Fis Saúde.2020; 25:e0113. DOI: 10.12820/rbafs.25e0113 